\title{
From Traditional Institutions to Community Based Influencers: The Dynamics of Communicating Development in Rural Communities
}

\author{
*Emmanuel Tsadu GANA
}

\begin{abstract}
Development interventions in rural communities have over the years, been hinged on locating and involving various community stakeholders in the process of planning and implementation of development projects. While the emphasis has always been on the inclusion of community based organization/groups and traditional institutions in interventions as key to ensuring ownership of projects, this paper argues that there are also individuals in communities, i.e., community based influencers (CBI) that have the capacity to function as pivotal voices in the task of ensuring the actualisation of development interventions (DIs). Drawing from different experiences of community development interventions in Giwa Local Government of Kaduna State and Akko Local Government in Gombe State, this paper examines the role and dynamics of both Traditional Institutions and Community Based Individuals in the quest to ensure ownership, actualization of development initiatives, and the sustainability of such projects. The paper, therefore, proposes that certain individuals within communities just like traditional institutions/rulers are very important to the process of engaging with communities and as such, careful consideration should be taken in identifying and including such individuals in the process of communicating development.
\end{abstract}

Keywords: Community development, Popular culture, Traditional rulers, CBI, DIs

\section{Introduction}

It is generally accepted that the key to a successful community

*Emmanuel Tsadu GANA of the Department of Theatre and Performing Arts
Ahmadu Bello University, Zaria Email: tsaduemmanuel3@gmail.com 
intervention lie in the proper understanding of the community, its members and gaining their acceptance. Central to this process is the point of entry, where stake holders are identified, consulted and informed about goal, purpose, intentions and outcomes of the intended project. Traditional leaders happen to be the custodians of the popular culture of local communities. They constitute an important part of the dynamics of most communities. This is because they have an overwhelming influence on the community members. Traditional leaders continue to control most of the important rural survival strategies: allocation of land, natural resources, communal labour practices and in some instances law and order. This situates them as stakeholders within the community whose opinions and decisions are always respected and followed. Hence, to achieve a successful development intervention implies that the traditional leaders/institution of the target community must give their consent before community engagement can take effect. It is this consent that also further unlocks the participation of community based organizations and community members to key into and own the entire process of the development initiative.

Over the years, part of what I have come to understand in my engagement with local communities is that, there are certain individuals that are as influential as traditional institutions, individuals whose opinions and involvement in certain activities within the community ensures commitment and participation of the community members. Such people are what I refer to as Community Based Influencers (CBIs). Their presence and support helps to strengthen community mobilization and aids in galvanizing the human resources which are in abundance within the community to effectively take part in the processes leading to community action. The focus of this paper therefore, is on the dynamic role of traditional leaders, community based individuals in ensuring the success or failure of community interventions. Drawing on experiences from the field the paper highlights how community interventions can either go right or wrong if proper identification of community communication channels are not made. 
Development and the Imperative for Community Development The concept of development has over the years gone through a dynamic treatment. It has metamorphosed from just being a product of economic and infrastructural growth to being a process which is people centred and geared towards improving the conditions of human society. Laying a foundation for the conception of development which this paper aligns with, Rogers (1976) describes development as:

A widely participatory process of social change in a society, intended to bring about both social and material advancement (including greater equality, freedom, and other valued qualities) for the majority of the people through their gaining greater control over their environment (111).

The emphasis implicitly is on the inclusion of citizens in the process of deciding and turning around the social and material conditions that inhibit their wellbeing. Rather than placing the demands of human growth and development on the indices of economic progression, the human centred development entertains engagement, sharing of feelings and collective planning. Providing further description of development, Wang and Dissanayake (1984) sees development as:

A process of social change which has as its goal the improvement of the quality of life of all or the majority of people without doing violence to the natural and cultural environment in which they exist, and which seeks to involve the majority of the people as closely as possible in this enterprise, making them the masters of their own destiny (p. 5).

Development as it is understood today is an outcome of a generic process of engagement, which translates in an increase of a collective or individual awareness to take action. This perception 
perhaps has played out most prominently in the arena of community development. Involving members of communities in the process of becoming active participants in solving inherent problems without reliance on government intervention is critical to the tenets of community development. As such, development initiatives have tended towards community-based development, because communities are deemed to have a better knowledge of the prevailing local conditions (such as who is poor and deserves to be helped, or the characteristics of the local micro-environment), and a better ability to enforce rules, monitor behaviour, and verify actions related to interventions (Platteau and Gaspart, 2003).

Community development therefore, translates to a social process by which human beings can become more competent to live with and gain some control over local conditions and the changing world. Hence, development is not likely to occur if the prevailing conditions of an environment are characterised by coercion through law and order, but is most likely to happen when all actors participate and share their ideas, visions and responsibilities equally and democratically in steering and implementing their community or village development projects (Ajayi and Otuya, 2006).

As such, communication is central to this process, as it is instrumental in ensuring that the members of a given community are given the opportunity to share and participate in the process of actualising their own development. Adedokun, Adeyemo and Olorunsola (2010, p. 101) describing the importance of communication to community development asserts:

Communication is a key component of sustainable development. Mobilizing community members for community development purpose is important but members of communities can only be mobilized when communication is effective. Adequate community communication leads to effective collaborative efforts in issue of development. 
To bring about social change among the marginalized and vulnerable population groups, participation must be fostered through communication. The type of communication referred to here is participatory communication; a communication process that is liberatory (Freire 1971), a communication processes which aims at empowering people within communities with the skill to discover issues affecting them, and negotiate on their own, ways to solving those problems and taking action. This type of communication is premised on the idea that, ñf development is to have any relevance to the people who need it most, it must start where the real needs existò (Melkote, 1991, p. 245). It must not be a process of co-opting or inducing community members into participating in interventions of which the solutions to the problems are already identified by external development agencies. One way of ensuring that development is properly communicated is to ensure that the community channels of communication are used as tools for engagement in the development process. The development that is envisaged is not merely a handout of benefits to people in need, but a process of empowerment where rural communities can acquire mastery over their own destiny through the realization that they, individually and collectively can do something to improve their circumstances.

\section{Traditional Leaders: A product of African popular Culture}

To begin with, it is imperative that this section contextualizes its understanding of culture. Culture is the sum total of a peoples way of life that embodies thinking, feeling, believing, the process of organizing, the setup of habitation, existence and development. It is the nexus of the ability to store, use and reuse societyôs knowledge and wisdom from the past to the present and also store them up for future use (Okwori, 2013). To put it clearly, culture encompasses the cumulative deposits of knowledge systems that manifests in traditions and customs of a people. These traditions and customs are sometimes popular cultural practices that give meaning and purpose to the collective existence of a group or society.

The idea of popular culture therefore is sometimes conceived as a quasi-mythical rural ñfolk cultureò. That which is 
considered common to and is a product of the living experiences of the people. If we are to go in the line of this assumption then it will imply that popular culture comprises the cultural practices peculiar to people. Such practices will therefore include festival celebrations, folk songs, dances, tales and other material artifacts that give meaning to a particular people. This however will fit into John Storeyôs (2006) description of popular culture as substandard culture that which is left over after high culture is determined. While this does not adequately provide a premise for a proper understanding of popular culture this paper will take the position of popular culture being a manifestation of tradition and customs.

Hence, suffice to say that popular culture as a manifestation of a peopleôs endogenous way of expression, finds its roots in the traditional cultural practices that establish meaning and order amongst a people. By tradition and traditional here it is meant $\tilde{n}$ a set of practices, normally governed by overtly or tacitly accepted rules of a ritual or symbolic nature, which seek to inculcate certain values and norms of behaviour by repetition, which automatically implies continuity with the past" (Hobsbawm and Ranger, 1994, p. 1). Consequently, traditional leaders are a product of customs and tradition which are accepted, deeply rooted and popular within societies. According to Adewumi and Egwurubeôs (1985, p. 20):

.. the group referred to as traditional
leaders/rulers are individuals occupying
communal political leadership positions
sanctified by cultural mores and values, and
enjoying the legitimacy of particular
communities to direct their affairs. ... Their
basis of legitimacy is therefore tradition,
which includes the whole range of inherited
culture and way of life; a peopleôs history;
moral and social values and the traditional
institutions which survive to serve those
values.


A very significant point to be gleaned from Adewunmi and Egwurubeôs submission is that traditional leaders are an intrinsic part of the way of life of a people. In another definition, ña traditional ruler is the traditional head of an ethnic unit or clan who for the time being is the holder of the highest traditional authority whose title is recognized as a traditional rulerôs title by the government of the stateò(Cookey, Alemika, Amucheazi, Oyebode, and Yahaya, 2010). This definition is favoured because if supports the creation of new traditional rulers to any deserving units or clans and emphasize the recognition of the state.

Hence, there is inarguably no history of an African society without reference to their traditional leaders. They are a popular symbol of tradition, culture, customs and their preservation. They are instrumental in ensuring growth and development in their communities through a well structured system of communication which ensures that grievances and issues of concern to the community members are well taken care of. Jahun $(2015$, p. 6) in describing the hierarchy and method of communication involved in settling matters in the traditional system of leadership in Northern Nigeria notes:

The official method of communication between the traditional rulers starts either from the top to the bottom or vice versa at all times. The Ward Head for example will only communicate with his District Head, and if the matter brought before the District Head is beyond his authority he will in turn forward the matter to Emirate Council or local Government depending on the nature of the matter. The case may go up to the state government level for final solution. This method is maintained religiously to avoid any breakdown of communication. This method of communication is 
maintained strictly to ensure discipline and

orderliness at all times in the emirates.

The process outlined above speaks much of the structural and orderly manner through which communal peace is maintained by the traditional institutions within which the leaders play a pivotal role. While it might be argued that the traditional institutional system is somewhat devoid of popularity because of its seeming exclusive reserve to a particular family, it is important to note that they remain ever closer to the people; and it is this closeness to the people that must be appreciated to achieve success in a development process.

\section{Leaders as Enhancers or Obstacles}

To start with, one very important approach in ensuring development is by giving the main actors (villagers living in the community) an equal opportunity to think and plan their own future. This underpins the need for effective leadership at the local community levels in order to harness the efforts of the rural people towards their own development (Orapin 1996). It is very important to note that there are two possible outcomes to the identification and involvement of community leaders in community development. When development workers do not properly communicate their intentions to community leaders, the whole process might be hijacked and truncated by leaders who are not responsible to their communities. In 2010 I was part of a group of researchers who ventured into a community called Pindiga in Akko local Government Area of Gombe State to understand the travails of tree felling within the community. Preliminary reports suggested that tree felling was the major source of income for the community.

As part of the strategy to gain access and entry into the community, the group identified the Village Head (the Dakaci of Pindiga) as the contact person, to facilitate the entire process of engagement with the community. Unfortunately, he saw it as an opportunity to meet his own needs. He deliberately refused to take the group to see the Emir of the area (whose palace is in the community) claiming that he had travelled. For every task we needed to accomplish he made a monetary request. He requested 
for finance to do virtually every task the group intended to accomplish, from mobilising community members for discussions, to making announcements about meetings. Perhaps he was already used to being co-opted and induced into participating in development activities and saw this as an opportunity to hijack the process for his own benefit. Another possible dimension to it is that he might have participated in political mobilization which are naturally monetized, and therefore saw the group as government agents who have come with a lot of money to share in the community. While these are possible misconceptions sometimes held by community leaders and members, development agents must be awake to the negative implication of such views to the actualization of development initiatives and therefore must devise ways of effectively communicating their intentions to the community. One effective way of doing this is to begin with communicating with the traditional institutions making clear the intention, objectives and goals of the initiative.

Hence, the Dakaciố attempt to hijack the process didnô just end there; as a way to encourage community members to imbibe the culture of tree planting, the group had deposited young tree plants (consisting economic trees like cashew, guava, mango and others like neem tree etc) in the home of the Dakaci. Over the night he removed all the economic trees and ordered that other ordinary young plants should be planted across the village. He kept the economic trees for himself. Rather than carry out his obligation to the community by being a custodian, ensuring that the community members are living in harmony and protecting their overall interest he is acting otherwise. This type of attitude by community leaders is what can lead to the truncation of the communication processes in development intervention within a community. It is in this light that Adie (2011, p. 35) raises a voice of caution:

Although villages seem so peaceful and the people very friendly in Nigeria, development agents should be aware that there are brutal power structures that control 
the lives of the poor and therefore become conscious of how to make the people come first, rather than creating an avenue for rural elite to grow richer and richer and powerful everyday to the detriment of the rural poor.

While community leaders can be obstacles to the process of communicating development they can also serve as enhancers to the entire process. Going back to the Pindiga experience what salvaged the intervention of the group was their insistence to see the Emir. After close contact with the Emir, who received the group with excitement, the entire process and activity carried out in the community became popular with the community members. The Emir himself made it a point of duty to check up on the discussions we were having with community members and assisted by providing transportation around the community. This results from the fact that the Emir identified with the initiative and expressed excitement over the possibilities of improving the lives of the members of his community. The success of any development project depends on whether it has good machinery for monitoring and evaluation. Monitoring and evaluation is necessary in order to ensure compliance to targeted objectives. As such, after the action plan was drawn out by the community the Emir also helped to provide the link between the community members and the ministry of forestry in Gombe State in order to help sustain and build on the efforts made by the group. This underscores the popularity of the authority and influence of traditional rulers which can be harnessed for developmental purposes.

Thus, good leadership is essential to bring a rural community to action, when good leadership is provided, just as exemplified by the Emir in Pindiga then the community members will be predisposed to participate voluntarily in the accomplishment of stated objectives as Ozor and Nwankwo (2008) further argue that ñthe approach to rural community development is always through local leaders who not only act as pioneers of projects but also help in influencing and motivating their people to action. For any rural community development to be successful, 
influential local leaders must be involvedé .ò ( $p$. 64). The implication of this is that interventions will go smoothly when traditional leaders who happen to be popular amongst community members are involved in the processes of initiating development selflessly.

\section{An Individual with Many Voices}

While it has been established that traditional leaders guarantee the involvement and participation of community members in communicating development interventions in communities, there are individuals within communities that have attained popularity as a result of their competence or vast experience. Such people which this paper refers to as community based influencers, play a similar role to that which traditional leaders play. Although they do not function in the same capacities as the institutional traditional leaders, they exude some significant influence over community members. In 2011 I came in contact with Mallam Usman Dogonyaro a member of a community called Nassarawa in Giwa local Government Area of Kaduna State. I was part of a team that visited the community for a Development communication field experience. Our task was to experience firsthand the self help activities which the community was engaged in, and to encourage community members to be self reliant.

The idea of self help is very critical to community development as individuals within communities need to realize and take up responsibility to ensure that certain things work well to the benefit of their collective existence. Mallam Usman Dogonyaro represents what we referred to as a community based influencers. He independently mobilized community members to take part in the activities. The community members looked up to him and his presence at the various discussion fora held in the community spurred community members to participate in the entire process of the experiment. He spoke less, but his views were always representative of and carried the collective feelings of the community members. In as much as such individuals can contribute immensely to the development process, it is also critical for interventionists to properly manage such 
individuals/influencers as they can also be counterproductive to the entire process in situations where they are overbearing and dominating.

Communicating development through community development strategy, interventionist must recognize that community based influencers are also channels for ensuring the participation, ownership, and success of development initiatives. Their involvement is very critical, as local leaders; they are an ñndispensable set in any community. In situations where such leaders are dedicated, honest, and hardworking, the community tends to develop rapidly amidst living in peaceò (Ozor and Nwankwo, 2008). However, there participation is not a guarantee for an intervention to end up as a total success. Caution must be taken to ensure that the community based influencers do not hijack the process to fuel their own personal idiosyncrasies.

\section{Conclusion}

Community involvement and participation is very critical to communicating development. As established in the body of this paper, traditional leaders and community based influencers must be identified as key stakeholders in the process of engendering a development that is a result of a peopleôs collective understanding and action. While traditional leaders provide the certainty for continuityô ownership and follow-through, the community based individual promotes collective responsibility amongst members of a community. The identification of these strengths within a community portends success for communicating development in rural communities. 


\section{References}

Adedokun, R., Adeyemo, C. W., and Olorunsola, E. O. (2010). The Impact of Communication on Community Development. Journal of Communication, 1(2), 101-105.

Adewumi, J. B., and Egwurube, J. (1985). ñRole of traditional rulers in historical perspectiveò. In Aborisade, Oladimeji (Ed.). Local government and the traditional rulers in Nigeria. Ile-Ife: University of Ife Press.

Adie, E. U. (2011). Theatre for development as tool for deconstructing power in development Interventions: The example of the Theatre Experience in Deba Community of Gombe State. Unpublished M.A thesis submitted to the Department of Theatre and Performing Arts, Ahmadu Bello University, Zaria.

Ajayi, A. R., and Otuya, N. (2006). Womenôs participation in selfhelp community development projects in Ndokwa agricultural zone of Delta State, Nigeria. Community Development Journal, 41 (2), 189-209.

Cookey, S. J. S., Alemika, E., Amucheazi, E., Oyebode, A.B., and Yahaya, A.D. (2010). Traditional Rulers in Nigeria. Ibadan: Safari Books Ltd.

Freire, P. (1970). Pedagogy of the oppressed. New York: Seabury Press.

Hobsbawm, E., and Ranger, T. (1994). The invention of tradition. Cambridge: Cambridge University Press. http://siteresources.worldbank.org/INTPUBSERV/Resourc es/platteau3.pdf.

Jahun, S. I. (2015). The roles and the challenges of traditional rulers in land conflicts and management in Nigeria. FIG working week: Sofia, Bulgaria. Retrieved 25 June, 2017, from

https://www.fig.net/resources/proceedings/fig proceedings/ fig2015/papers/ts07f/TS07F_jahun,_saidu_7577.pdf

Okwori, J. Z. (2013). The culture of creativity and the creativity of culture: Implications for peace and national development. A presentation at the 2013 world day for cultural diversity, 
dialogue and development, International Conference Centre, Abuja, May 21, 2013.

Orapin, S. (1996). Peopleôs participation in community development. TDRI Quarterly Review, 11 (3), 19-25.

Ozor, N., and Nwankwo, N. (2008). The role of local leaders in community development programmes in Ideato local government area of Imo State: Implication for extension policy. Journal of Agricultural Extension, 12 (2), 63-75.

Platteau, J.P., and Gaspart, F. (2003). ñDisciplining local leaders in community-based development. Centre for Research on the Economics of Development (CRED), Namur Belgium. Retrieved 20 August, 2006, from http://aldilah-bagasd.blog.ugm.ac.id/2013/07/18/disciplining-local-leaders-incommunity-based-development/. 